\title{
Quality and Nutritional Status of Fresh-cut Tomato as Affected by Spraying of Delactosed Whey Permeate Compared to Industrial Washing Treatment.
}

\author{
Lubna Ahmed \\ Technological University Dublin, lubna.ahmed@tudublin.ie \\ Ana Belen Martin-Diana \\ Technological University Dublin, anabelen.martindiana@tudublin.ie \\ Daniel Rico \\ Technological University Dublin, daniel.rico@tudublin.ie
}

See next page for additional authors

Follow this and additional works at: https://arrow.tudublin.ie/schfsehart

Part of the Food Chemistry Commons

\section{Recommended Citation \\ This Article is brought to you for free and open access by the School of Food Science and Environmental Health at ARROW@TU Dublin. It has been accepted for inclusion in Articles by an authorized administrator of ARROW@TU Dublin. For more information, please contact arrow.admin@tudublin.ie, aisling.coyne@tudublin.ie, gerard.connolly@tudublin.ie.}

Ahmed, L., Martin-Diana, A., Rico, D. and Barry-Ryan, C. (2012). Quality and Nutritional Status of Fresh-cut Tomato as Affected by Spraying of Delactosed Whey permeate Compared to Industrial Washing Treatment. Food and Bioprocess Technology, 2012, 5 (8) pp 3103-3114. DOI: 10.1007/s11947-011-0623-6

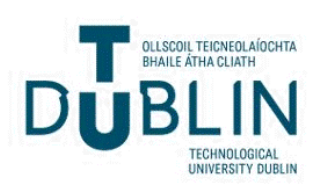




\section{Authors}

Lubna Ahmed, Ana Belen Martin-Diana, Daniel Rico, and Catherine Barry-Ryan 
Full Title

2

3 Quality and Nutritional status of Fresh-cut Tomato as affected by Spraying of Delactosed Whey Permeate compared to Industrial Washing Treatment

5

6

7

8

Shelf-life Extension of Tomatoes by DWP

9

10

11

12 Lubna Ahmed ${ }^{\mathrm{a} *}$, Ana B. Martin-Diana ${ }^{\mathrm{b}}$, Daniel Rico ${ }^{\mathrm{b}}$ and Catherine Barry-Ryan ${ }^{\mathrm{a}}$

14

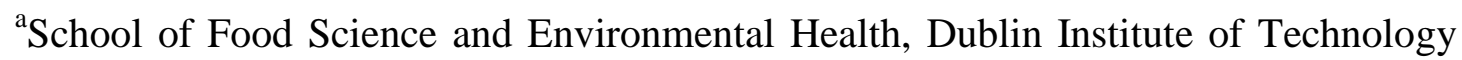

17

(DIT), Cathal Brugha Street, Dublin 1, Ireland.

18

${ }^{\mathrm{b}}$ Agro Technological Institute of Castilla and Leon (ITACYL). Government of

19 Castilla and Leon, Finca Zamadueñas, Valladolid, Spain.

20

21

22

23

*Corresponding Author: Lubna Ahmed, School of Food Science and

24 Environmental Health, Dublin Institute of Technology (DIT), Cathal Brugha Street,

Dublin 1, Ireland. Phone: 35314024442, Fax: +35314024495, e-mail: lahmed@dit.ie 
The aim of this study was to examine the applicability of delactosed whey permeate (DWP) treatment on preserving the quality and antioxidant attributes of fresh-cut tomato. Tomatoes were treated with $3 \%$ DWP by dipping, spraying and a

31 combination of both, stored at $4{ }^{\circ} \mathrm{C}$ for 10 days and compared with the industrial 32 standard, chlorine. The combination of dipping and spraying of DWP showed the best results for all the markers tested. The combined treatment of dipping and spraying of DWP significantly lowered total counts $(\sim 1.0 \log \mathrm{cfu} / \mathrm{g})$, yeast and moulds $(\sim 1.2 \log$ cfu/g), inhibited the loss of firmness (25\%) and reduced POD activity (15\%) of the tomato slices after 10 days compared to the chlorine treatment. Moreover, DWP treated tomatoes maintained significantly $(\mathrm{p}<0.05)$ higher levels of vitamin $\mathrm{C}$, total phenols (TP) and antioxidant activity (DPPH) than the chlorine treated samples during storage. Sensory scores confirmed that DWP treated tomatoes retained better aroma and texture. Also, the appearance and overall acceptability were higher than

41 chlorine treated tomatoes. Thus DWP treatment has potential to extend the shelf-life 42 of fresh-cut tomatoes.

43

44 Key words: Whey permeate; Fresh-cut; Tomato; Shelf-life; Quality, Antioxidants. 


\section{Introduction}

47 Tomato (Lycopersicon esculentum Mill.) is a versatile vegetable that is consumed fresh as well as in the form of processed products (Toor \& Savage, 2005). It is considered as an important source of dietary antioxidants as it is rich in vitamins, carotenoids and phenolic compounds (Lenucci et al., 2006). Results from epidemiological studies have shown that high consumption of tomato fruit is consistently correlated with a reduced risk of chronic diseases such as cardiovascular disease and certain types of cancer (Sgherri et al., 2008). The increase in the consumers' awareness of the health benefits of fruits and vegetables and the emerging need for convenience due to a fast-paced lifestyle is leading to an increasing demand of fresh-cut fruits and vegetables (Odriozola-Serrano et al., 2008). Retention of the quality and shelf-life of these products during storage is now the interest of the industry and consumers (Camargo et al., 2010). Fresh-cut fruit and vegetables should offer consumers highly nutritious, convenient and healthy food while still maintaining the desired freshness. However, as a result of peeling, cutting and preparation of ready-to-eat fruits and vegetables, a large number of physiological phenomena such as biochemical changes and microbiological spoilage take place and may result in degradation of colour, texture, and flavour. The marketing of fresh-cut vegetables is limited by their short shelf-life due to quick decline in post-processing quality. Chlorinated water (50-200 ppm) is widely used to wash fruits and vegetables as well as fresh-cut produce in order to preserve their quality (Ahmed et al., 2011a, b). However, the possible formation of carcinogenic chlorinated compounds in water (chloramines and trihalomethanes) has called into question the use of chlorine for this purpose (Alegria et al., 2010). In recent years interest is growing in the use of natural products for the preservation of fresh-cut produce. Research and commercial 
applications have shown that natural components could replace traditional washing agents (Rojas-Graü et al., 2009). The development of chlorine-free fruit and vegetable products enriched with natural bio-products could contribute greatly to a new and growing market, where the consumers' concerns about their health are met.

Whey permeate is a by-product of the production of whey protein concentrates from cheese whey. The main composition of whey permeate are water, lactose, low molecular peptides and minerals. Whey and whey ultrafiltrated permeate have been proposed to be used as a natural antioxidant in foods (Contreras et al., 2011). Whey proteins and peptides (Lactoferrin, $\alpha$-lactalbumin and $\beta$-lactoglobulin, casein macro peptide, $\alpha_{1-}$ and $\alpha_{2}$-caseins) exhibit a growing number of biological effects including anti-hypertensive, anti-cancer, hypocholesterolemic, opiodergic, and anti-microbial activities (Román et al., 2011; Yalcin, 2006). They are also a rich source of the amino acids - lysine, leucine, threonine, tryptophan and cysteine. Whey could be a promising natural bio-active alternative to chlorine. Martin-Diana et al. (2006) used acidic whey permeate for washing fresh-cut lettuce and carrots during storage. Whey protein has been found to reduce the enzymatic browning of 'Golden Delicious' apples (PerezGago et al., 2006). Coronado et al. (2002) successfully used rosemary extract and whey powder for the oxidative stability of wiener sausages during 10 months frozen storage. Whey is used as a fermentation feedstock for the production of lactic acid, acetic acid, propionic acid, ethanol, and single cell protein, etc (Panesar et al., 2007). However, these applications still do not utilise all the whey produced and new uses for this by-product are needed as the high chemical oxygen demand (COD) (50 kg $\mathrm{O}_{2} /$ ton permeate) of whey makes its disposal a cost-effective and significant pollution problem. 
95 Therefore the aim of this study was to explore the effect of different application methods of delactosed whey permeate treatment on the quality and antioxidant components of fresh-cut tomatoes during storage as an alternative to chlorine.

\section{Materials and Methods}

\subsection{Sampling}

Irish vine ripened tomatoes (Lycopersicon esculentum L. Mill.) cv. Moneymaker were purchased from a local supermarket (Dunnes Stores). According to the grower, the tomato plants were grown commercially in a greenhouse with a $14 \mathrm{~h}$ light period from February until November. The aerial environment of the greenhouse and crop irrigation and nutrition were precisely controlled. The temperature of the greenhouse was $16-21{ }^{\circ} \mathrm{C}$ which is optimum for lycopene synthesis in tomato fruits. The tomatoes were then brought to the food processing lab and stored at $4{ }^{\circ} \mathrm{C}$ before processing. The experiments were carried out between April to September 2010.

\subsection{Preparation of Treatment Solution}

Liquid delactosed whey permeate was kindly supplied by Glanbia Ltd. Ingredients, Ireland. Delactosed whey permeate (DWP) was obtained after removal of lactose crystals from whey permeate. The $\mathrm{pH}$ for DWP solution was 5.0.

\subsection{Processing}

Whole tomatoes were rinsed in water prior to washing in order to avoid soil contamination. Washing treatment was performed by applying $3 \%$ DWP solution in three different ways such as dipping, spraying and a combination of both. In case of dipping treatment, whole tomato was dipped in DWP solution (200 g tomatoes/L) for $1 \mathrm{~min}$ (with agitation). In case of spraying treatment, the tomatoes were sliced $6 \mathrm{~mm}$ in thickness with a commercial slicing machine (Maxwell chase MCT-25, Baltimore 
119 Innovations, UK) and $3 \%$ DWP treatment solution were sprayed over the sliced

120 tomato. In case of the combination of dipping and spraying, tomatoes were treated

121 with $3 \%$ DWP in both ways. For control samples, tomatoes were dipped into 120

122 ppm chlorine solution ( $\mathrm{pH}$ 8.0) for 1 min (Delaquis et al., 2004). The tomato slices

123 were then air-dried for 30 mins in RT. Processed tomatoes were then pooled, mixed

124 and $\sim 100$ grams placed in a polypropylene tray $(180 \mathrm{~mm}$ length $\times 130 \mathrm{~mm}$ width $\times 25$

$125 \mathrm{~mm}$ depth) from Sharp Interpack Ltd., UK containing one layer of absorbent paper on

126 the bottom (Fresh-R-Pax absorbent pads, Maxwell Chase Technologies, Atlanta). The

127 principal ingredient in fresh-R-Pax absorbent pads is food grade sodium

128 carboxymethyl cellulose (CMC), a common ingredient in ice-cream, sauces, low-fat

129 foods, etc. The trays were then packed in bags $(200 \times 320 \mathrm{~mm})$ of $35 \mu \mathrm{m}$ oriented

130 polypropylene film (OPP) with permeability at $23{ }^{\circ} \mathrm{C}$ and $90 \% \mathrm{RH}$ of $3.3 \times 10^{-12}$

$131 \mathrm{~mol} / \mathrm{s} / \mathrm{m}^{2} / \mathrm{Pa}$ for $\mathrm{O}_{2}$ (Amcor Flexibles Europe-Brighouse, United Kingdom). The

132 packages were then heat-sealed under atmospheric conditions and stored at $4{ }^{\circ} \mathrm{C}$ for

13310 days (Ahmed et al., 2011a).

134 2.4. Markers Analysis of Fresh-cut Tomato

135 Different quality (headspace gas composition, colour, $\mathrm{pH}$ and firmness), sensorial and

136 nutritional markers (ascorbic acid, lycopene, total phenols, antioxidant activity as

137 measured by DPPH), enzymatic activity (POD and PME) and microbial enumerations

138 (total aerobic counts and yeast and moulds) of fresh-cut tomato were monitored

139 throughout the 10 days of storage at $4{ }^{\circ} \mathrm{C}$.

140 2.4.1. Quality Markers

141 2.4.1.1. Headspace Gas Composition 
142 Changes in $\mathrm{O}_{2}$ and $\mathrm{CO}_{2}$ concentration of the headspaces of the fresh-cut tomatoes 143 packages were monitored during the shelf-life of fresh-cut tomatoes. A Gaspace 144 analyser (Systech Instruments, UK) was used to monitor $\mathrm{O}_{2}$ and $\mathrm{CO}_{2}$ levels. Gas 145 extractions were performed with a hypodermic needle, inserted through an adhesive 146 septum previously fixed to the bags, at a flow rate of $150 \mathrm{ml} / \mathrm{min}$ for $10 \mathrm{sec}$. Three

147 bags per treatment were monitored for each experiment and all bags for other analyses 148 were checked before analysis (Ahmed et al., 2011b).

\section{2.4.1.2. Colour}

150 For colour analysis each piece of tomato in the storage pack was analysed

151 individually to minimise the variability of the product. Colour was quantified using a 152 Colour Quest XE colorimeter (HunterLab, Northants, UK). A tomato slice was placed 153 directly on the colorimeter sensor $(3.5 \mathrm{~cm}$ of diameter) and measured. $20-30$ 154 measurements were taken per treatment and day. The $\mathrm{L}^{*}$ parameter (lightness index 155 scale) range from 0 (black) to 100 (white). The $\mathrm{a}^{*}$ parameter measures the degree of 156 red $\left(+a^{*}\right)$ or green $\left(-a^{*}\right)$ colour and the $b^{*}$ parameter measures the degree of yellow $157\left(+b^{*}\right)$ or blue $\left(-b^{*}\right)$ colour. The CIE L* $a^{*} b^{*}$ parameters were converted to Hue

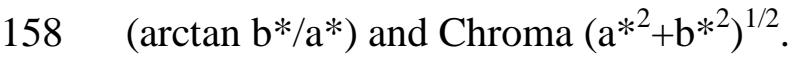

159 2.4.1.3. $p H$

160 For $\mathrm{pH}$ value $10 \mathrm{~g}$ of tomato tissue were blended for $2 \mathrm{~min}$. The $\mathrm{pH}$ was measured at 161 room temperature using an Orion research $\mathrm{pH}$-meter, UK.

\subsubsection{Firmness}

163 Four measurements were made on each slice, two in the outer pericarp and two in the

164 radial pericarp, applying the force in the axial direction. The force necessary to cause

165 a deformation of $3 \mathrm{~mm}$ with a speed of $0.02 \mathrm{~mm} / \mathrm{s}$ was recorded using a an Instron 
166

texture analyser (Instron 4302 Universal Testing Machine, Canton MA, USA), with a $3.5 \mathrm{~mm}$ diameter flat faced cylindrical probe. Only the central slice in the stack was used in the analyses. The firmness measurement was performed immediately after removing the slice from the storage chamber (at storage temperature). Data were analysed with the Instron series IX software for Windows.

\subsubsection{Enzymatic Activity}

\subsubsection{Browning-related Enzyme - Peroxidase (POD)}

POD enzyme was assayed in homogenates that were prepared as follows: $10 \mathrm{~g}$ of tomato puree was placed in a $100 \mathrm{ml}$ beaker in a 1:2(w:v) ratio with $0.5 \mathrm{M}$ phosphate buffer, $\mathrm{pH}$ 6.5, containing $50 \mathrm{~g} / \mathrm{l}$ polyvinylpyrrolidone. Then homogenisation was carried out twice with an Ultra-Turrax T-25 tissue homogeniser at $4{ }^{\circ} \mathrm{C}$ and 20,500 $\mathrm{rpm}$, for 1 min each time with a break of 3 min between homogenisations to avoid excess heating of the sample. The homogenate was centrifuged at $12,720 \mathrm{~g}$ for $30 \mathrm{~min}$ at $4{ }^{\circ} \mathrm{C}$. It was then filtered through Whatman no. 4 filter paper. The resulting crude extract was used without further purification. All the extracts were kept at $4{ }^{\circ} \mathrm{C}$ in the dark and used immediately (within $1 \mathrm{hr}$ ). POD activity was assayed spectrophotometrically by a modified method based on Martin-Diana et al. (2006). The reaction mixture contained $0.2 \mathrm{ml}$ of extract and $2.7 \mathrm{ml}$ of $0.05 \mathrm{M}$ phosphate buffer, $\mathrm{pH} 6.5$, containing $1.85 \mathrm{ml}$ of hydrogen peroxide $(1.5 \%, \mathrm{v} / \mathrm{v})$ as oxidant and $3.7 \mathrm{ml}$ of $\mathrm{p}$-phenylendiamine as hydrogen donor. The oxidation of $\mathrm{p}$-phenylendiamine was monitored at $485 \mathrm{~nm}$ and $25^{\circ} \mathrm{C}$. A unit of enzyme activity was defined as an increase of 0.1 absorbance units per minute.

\subsubsection{Texture-related Enzyme - Pectin Methyl Esterase (PME)}


PME activity was measured using the method described by Yoo et al. (2009). Ten grams of tomato puree was diluted in an extraction solution $(0.2 \mathrm{M}$ sodium phosphate buffer, $\mathrm{pH} 7.5$ containing $1 \mathrm{M}$ sodium chloride and $10 \mathrm{mM}$ dithiothreitol) and homogenised at $4{ }^{\circ} \mathrm{C}$ for $2 \mathrm{~min}$ at $5,500 \mathrm{rpm}$. The macerate was incubated at $4{ }^{\circ} \mathrm{C}$ for $30 \mathrm{~min}$ with agitation and centrifuged at $12,720 \mathrm{~g}$ for $30 \mathrm{~min}$ at $4{ }^{\circ} \mathrm{C}$. It was then filtered through Whatman no. 4 filter paper. One $\mathrm{ml}$ of this extract was mixed with 40 $\mathrm{ml}$ of substrate solution (1\% pectin). The solution was adjusted to $\mathrm{pH} 7.0$ with $1.0 \mathrm{M}$ $\mathrm{NaOH}$, and the $\mathrm{pH}$ of the solution was readjusted to $\mathrm{pH} 7.5$ with $0.05 \mathrm{M} \mathrm{NaOH}$. After the $\mathrm{pH}$ reached $7.5 ; 0.2 \mathrm{ml}$ of $0.05 \mathrm{~N} \mathrm{NaOH}$ was added. The time required to return to $\mathrm{pH} 7.5$ was recorded. Activity was quantified as carboxyl groups formed by the hydrolysis of methyl esters of pectin and was measured tritrimetrically using a $\mathrm{pH}$ electrode to monitor the production of $\mathrm{H}^{+}$. The enzymatic activity was expressed as:

$P M E=\frac{0.2[\mathrm{~mL}] \mathrm{NaOH} * 0.05\left[\mathrm{Mol} \cdot \mathrm{L}^{-1}\right] \mathrm{NaOH} \cdot \mathrm{X}[\mathrm{mL}] \cdot 10^{3}\left[\mathrm{mMol} \cdot \mathrm{Mol}^{-1}\right] \cdot 10^{3}\left[\mathrm{~L} \cdot \mathrm{mL}^{-1}\right]}{Y[\mathrm{~mL}] \cdot \mathrm{Z}[\mathrm{g}] \cdot \operatorname{time}[\mathrm{min}]}$

Where, $\mathrm{X}=$ total volume $(\mathrm{ml})$ extracted, $\mathrm{Y}=$ volume used $(1 \mathrm{ml})$ in the assay, $\mathrm{Z}=$ sample used in the assay (10 g). Three macerates per treatment and day were prepared. Triplicates of the enzymatic activity were analysed.

\subsubsection{Sensory Analysis}

A panel of 12 judges aged 20 - 35 years (postgraduate students of the School of Food Science and Environmental Health, DIT) was trained in discriminate evaluation of fresh-cut tomato. Panellists were required to score changes in fresh appearance, texture, aroma and general acceptability. Before starting the sensory experiments, panellists were familiarised with the product and scoring methods. This consisted of demonstration exercises involving examination of fresh-cut tomatoes at different levels of deterioration and agreeing appropriate scores. After becoming familiar with 
213 the test facilities and scoring regime, they were invited to score samples. This

214 procedure was repeated several times until a level of consistency in scoring was

215 obtained. Fresh appearance, texture, aroma and general acceptability of tomato

216 samples were scored on a scale of 1 to 9 , where a score of one indicated a product of

217 very poor quality, etc. (Ferreira et al., 2008). The evaluation was carried out in the

218 sensory evaluation laboratory. Products were placed in plastic cups with lid, on a

219 white surface and judges were isolated from each-other in a booth in an odour-free

220 environment. Samples were presented in randomised order to minimise possible

221 sequence influence. The results of the sensory analysis were reported as means of 222 three separate trials. Data were analysed using Compusense® Five software (Release 223 4.4, Ontario, Canada).

\section{2.4.4. Nutritional Markers}

\subsubsection{Ascorbic Acid}

226 The ascorbic acid content in fresh-cut tomatoes was analysed by high performance 227 liquid chromatography (HPLC) following the method described by Lee \& Castle 228 (2001) with a slight modification. A 25-ml of $6 \%$ meta-phosphoric acid (pH 3.0) was 229 added to $2.5 \mathrm{~g}$ of tomato samples. The sample was homogenised for $1 \mathrm{~min}$ at 24,000 230 rpm using an Ultra-Turrax T-25 Tissue homogeniser. Then the sample was shaken 231 with a Gyrotory Shaker G-2 (USA) for $2 \mathrm{hrs}$ at $150 \mathrm{rpm}$ and centrifuged for $15 \mathrm{~min}$ at $2323,000 \mathrm{~g}$ at $4{ }^{\circ} \mathrm{C}$ (Sanio MSE Mistral 3000ii, UK). Following centrifugation, $10 \mathrm{ml}$ of 233 the supernatant was filtered through PTFE syringe filters (pore size $0.45 \mu \mathrm{m}$, 234 Phenomenex, UK) and stored at $-20^{\circ} \mathrm{C}$ in foil covered plastic test tubes for further 235 analysis by HPLC. The analysis of ascorbic acid content was performed with Waters 236600 Satellite HPLC, with a reverse phase analytical polymeric $\mathrm{C}_{18}$ column $(150 \times 4.6$ $237 \mathrm{~mm}, 5 \mu \mathrm{m}$ ) (Waters, Ireland) with a UV-tunable absorbance detector (Waters 486) at 
$238230 \mathrm{~nm}$. Ten $\mu \mathrm{l}$ of the sample was injected. An isocratic mobile phase of $25 \mathrm{mM}$ 239 monobasic potassium phosphate ( $\mathrm{pH} \mathrm{3.0)}$ with a flow rate of $1.0 \mathrm{ml} / \mathrm{min}$ was used.

240 Five concentrations of ascorbic acid standard in $6 \%$ meta-phosphoric acid in the

241 range $10-50 \mu \mathrm{g} / \mathrm{ml}$ were injected.

242 2.4.4.2. Lycopene

243 Ten grams of tomato samples were weighed and transferred into a $100 \mathrm{ml}$ beaker 244 (wrapped with aluminium foil). A 50-ml volume of hexane-acetone-ethanol solution $245(2: 1: 1 \mathrm{v} / \mathrm{v} / \mathrm{v})$ containing $2.5 \%$ BHT was added to solubilise the lycopene (Shi \& Le 246 Maguer, 2000). Following this the samples were homogenised with an Ultra-Turrax 247 T-25 tissue homogeniser for $1 \mathrm{~min}$ at 20,500 rpm. The samples were then shaken with 248 a Gyrotory Shaker G-2 (USA) for $2 \mathrm{hrs}$ at $150 \mathrm{rpm}$ followed by $10 \mathrm{ml}$ of distilled 249 water was added and stirred for additional $10 \mathrm{~min}$. The polar and non-polar layers 250 were separated, and the upper hexane layer was collected and filtered through a 0.45 $251 \mu \mathrm{m}$ PVDF membrane filter. It was transferred to a new $15 \mathrm{ml}$ aluminium wrapped test 252 tubes and kept at $-80{ }^{\circ} \mathrm{C}$ for analysis. The analysis of lycopene was performed with 253 Waters 600 Satellite HPLC, with a reverse phase analytical polymeric $\mathrm{C}_{18}$ column $254(150 \times 4.6 \mathrm{~mm}, 5 \mu \mathrm{m})$ (Waters, Ireland) with a UV tunable absorbance detector 255 (Waters 486) for spectrometric peak. The lycopene peaks were identified at $475 \mathrm{~nm}$. 256 An isocratic mobile phase of methyl t-butyl ether/methanol/ethyl acetate (40:50:10, $257 \mathrm{v} / \mathrm{v}$ ) with a flow rate of $1 \mathrm{ml} / \mathrm{min}$ was used. The column temperature and mobile phase 258 was maintained at $25^{\circ} \mathrm{C}$. Analyses were performed under dim light to prevent sample 259 degradation by photo-oxidation. Three concentrations of lycopene standard in the 260 range $0.01-0.03 \mathrm{mg} / \mathrm{ml}$ were injected. 
262 For extraction of total phenol content $1.25 \mathrm{~g}$ of tomato sample was weighed and $25 \mathrm{ml}$

263 of methanol was added. Following this the sample was homogenised in a $50 \mathrm{ml}$ tube

264 with an Ultra-Turrax T-25 tissue homogeniser for $1 \mathrm{~min}$ at 24,000 rpm. The samples

265 were then thoroughly mixed with a vortex mixer (V400 Multitude Vortexer, Alpha

266 laboratories) for $2 \mathrm{hrs}$ at $150 \mathrm{rpm}$. Then it was centrifuged for $15 \mathrm{~min}$ at 3,000 $\mathrm{g}$ using

267 a Sanyo MSE Mistral 3000i, UK. Following centrifugation, $10 \mathrm{ml}$ samples of the

268 supernatant were filtered through PTFE syringe filters (pore size $0.45 \mu \mathrm{m}$,

269 Phenomenex, UK). Finally the extracts were stored at $-20{ }^{\circ} \mathrm{C}$ in foil covered plastic

270 test tubes for further analysis. Total phenol content of tomatoes was determined using

271 the Folin-Ciocalteu method (Singleton et al., 1999). In a $1.5 \mathrm{ml}$ Eppendorf tube, 100

$272 \mu \mathrm{l}$ of appropriately diluted methanolic extract, $100 \mu \mathrm{l}$ of $\mathrm{MeOH}$ and $100 \mu \mathrm{l}$ of $\mathrm{FC}$

273 reagent were added and vortexed. After exactly $1 \mathrm{~min}, 700 \mu \mathrm{l}$ of sodium carbonate

274 (20\%) was added, and the mixture was vortexed and allowed to stand at room

275 temperature in the dark for $20 \mathrm{~min}$. Then the tubes were centrifuged at $12,720 \mathrm{~g}$ for 3

276 min. The absorbance of the supernatant was read at $735 \mathrm{~nm}$ in $1 \mathrm{ml}$ plastic cuvettes.

277 The blank was $\mathrm{MeOH}$. Each sample of the three batches was measured in triplicate.

278 Results were expressed as mg/L Gallic acid equivalents (GAE).

279 2.4.4.4. Antioxidant Activity Test - 2, 2-Diphenyl-l-picrylhydrazyl Radical 280 Scavenging Capacity Assay (DPPH)

281 DPPH scavenging activity assay was performed as per the method described by 282 Sanchez-Moreno (2002) with a slight modification. For extraction, $1.25 \mathrm{~g}$ of tomato 283 sample was weighed and $25 \mathrm{ml}$ of methanol was added to it. Following this the 284 sample was homogenised in a $50 \mathrm{ml}$ tube with an Ultra-Turrax T-25 tissue 285 homogeniser for $1 \mathrm{~min}$ at 24,000 rpm. The sample was then thoroughly mixed with a 286 vortex mixer (V400 Multitude Vortexer, Alpha laboratories) for $2 \mathrm{hrs}$ at $150 \mathrm{rpm}$. 
Then the sample was centrifuged for $15 \mathrm{~min}$ at 3,000 rpm using a Sanyo MSE Mistral 3,000i, UK. Following centrifugation, $10 \mathrm{ml}$ samples of the supernatant were filtered through PTFE syringe filters (pore size $0.45 \mu \mathrm{m}$, Phenomenex, UK). Finally the extracts were stored at $-20{ }^{\circ} \mathrm{C}$ in foil covered plastic test tubes for further analysis. In a 1.5-ml Eppendorf tube $500 \mu \mathrm{l}$ of appropriately diluted methanolic extract and $500 \mu \mathrm{l}$ DPPH Reagent were added and vortexed. After that they were kept for $30 \mathrm{~min}$ in 293 dark. The absorbance of the supernatant was read at $515 \mathrm{~nm}$ in $1 \mathrm{ml}$ plastic cuvettes. 294 Each sample of the three batches was measured in triplicate.

\subsubsection{Microbial Analyses}

296 Microbiology analyses were carried out on the samples before and after the treatment 297 at regular intervals through the storage period. $25 \mathrm{~g}$ of tomatoes were blended in 225 $298 \mathrm{ml}$ of peptone water (Scharlau Chemie, S.A., Barcelona, Spain) with a Stomacher 299 circulator homogeniser (VWR, Dublin, Ireland). Enumeration and differentiation of 300 total aerobic counts were quantified at $30{ }^{\circ} \mathrm{C}$ in plate count agar (Scharlau Chemie, 301 S.A., Barcelona, Spain) over 72 hrs. Yeast and moulds were quantified at $25{ }^{\circ} \mathrm{C}$ in 302 potato dextrose agar (Scharlau Chemie, S.A., Barcelona, Spain) over 72 hrs. The 303 results were expressed as log colony forming units per gram $(\mathrm{cfu} / \mathrm{g})$.

\subsubsection{Statistical Analysis}

305 Data were analysed by multivariate analysis of variance (MANOVA) using 306 Statgraphics software (version: Centurium XV; Statistical Graphics Co., Rockville, 307 USA) for different washing treatments. Analysis of variance one-way (ANOVA) was 308 used to analyse each treatment over storage. In the case of significant differences the 309 LSD range test $(\mathrm{p}<0.05)$ was used.

\section{$310 \quad 3 . \quad$ Results and Discussion}




\subsubsection{Headspace Gas Composition}

313 Fig. 1 illustrates the changes of headspace gas $\left(\mathrm{O}_{2}\right.$ and $\left.\mathrm{CO}_{2}\right)$ composition inside the

314 fresh-cut tomato packages during the 10 days of storage. Both the oxygen and carbon

315 dioxide gas compositions significantly $(\mathrm{p}<0.05)$ changed over storage. The oxygen

316 gas decreased and the carbon dioxide gas increased throughout storage, as expected.

317 Oxygen decreased from atmospheric levels (21\% - packaging conditions) to values 318 around $15 \%$ by day 10 . A sharp increase in carbon dioxide was observed during 319 storage, from $1.0 \%$ to reaching values around $4.5 \%$ at day 10 . The final 320 concentrations for both gases in the fresh-cut tomato packages stored at $4{ }^{\circ} \mathrm{C}$ were 321 between the tolerance limits for this commodity which are neither lower than $10 \%$ for 322 oxygen nor higher than $15 \%$ for carbon dioxide (Villanueva et al., 2005). Similar gas 323 concentration levels at day 10 were also described by Artés et al. (1999) using passive 324 MAP where the fresh-cut tomatoes retained good quality. Gil et al. (2002) also found 325 this increase in $\mathrm{CO}_{2}$ after cutting of fresh tomatoes. There was no significant $(\mathrm{p}<0.05)$ 326 difference among the control and the DWP treatments for headspace gas composition 327 as the changing pattern of the gases was the same over time.

\section{3.1.2. Colour}

329 Colour is one of the most important factors in the perception of the quality of fresh330 cut fruits and vegetables. In the present study, fresh-cut tomatoes showed a significant 331 decrease $(p<0.05)$ in luminosity during storage (Table 1). Lana et al. (2006) also 332 found a similar trend. There were significant $(\mathrm{p}<0.05)$ differences in $\mathrm{L}^{*}$ values 333 between samples treated with DWP by spraying and samples treated with chlorine. 334 The other two DWP treatments did not show significant difference with the chlorine 
335 treatment. The parameters $\mathrm{a}^{*}$ and $\mathrm{b}^{*}$ were not significantly $(\mathrm{p}>0.05)$ affected by the

336 DWP treatment. The parameter $\mathrm{a}^{*}$ increased significantly $(\mathrm{p}<0.05)$ during storage.

337 The $\mathrm{a}^{*}$ value is an important parameter for red colour development and the degree of 338 ripening in tomato. Lana et al. (2006) also found the increase of a* values during 339 storage. However, the parameter $b^{*}$ decreased during storage for all treatments. Hue 340 and Chroma also decreased during storage and the decrease was more prominent in 341 samples treated with chlorine than samples treated with DWP, though not significant.

342 Hue is negatively correlated with the maturity of tomato. Hue decreases as tomato 343 matures during storage.

344 3.1.3. $\mathrm{pH}$

345 Significantly $(\mathrm{p}<0.05)$ higher $\mathrm{pH}$ was observed for the control samples (chlorine) than 346 samples treated with DWP (Fig. 2A). At day 10 the lowest $\mathrm{pH}$ appeared in samples 347 washed with DWP by a combination of dipping and spraying method, followed by 348 spraying only. Tomatoes treated with DWP by dipping had the highest $\mathrm{pH}$ among the 349 three DWP treatments, though the difference with the tomatoes treated with DWP by 350 spraying was not significant $(\mathrm{p}>0.05)$. The $\mathrm{pH}$ increased significantly $(\mathrm{p}<0.05)$ over 351 storage in all the samples. This is in agreement with Artés et al. (1999). The increase 352 in $\mathrm{pH}$ during storage might be associated with bacterial growth (Rico et al., 2007).

\subsubsection{Texture}

354 Texture (firmness) decreased significantly $(\mathrm{p}<0.05)$ during storage for all treatments 355 (Fig. 2B). These instrumental result correlated with the sensory panel's texture scores 356 (Fig. 3). All three DWP treated samples maintained significantly $(\mathrm{p}<0.05)$ better 357 texture than chlorine treated samples. Significant differences $(\mathrm{p}<0.05)$ among DWP 358 treatments were also observed. Samples treated with DWP by a combination of 
dipping and spraying method maintained significantly higher texture throughout the

360 storage than samples treated with DWP dipping and DWP spraying. There was no

361 significant $(\mathrm{p}>0.05)$ difference between the samples treated with DWP dipping and

362 DWP spraying. The presence of calcium in whey permeates might help to maintain

363 the firmness of tomato during storage (Evans et al., 2010). Different calcium salts

364 have been used for firmness improvement of fresh fruits and vegetables. Calcium 365 carbonate and calcium citrate are the main calcium salts added to foods in order to 366 enhance the nutritional value. Calcium chloride has been widely used as preservative 367 and firming agent in the fruits and vegetables industry for whole and fresh-cut 368 commodities (Chardonnet et al., 2003).

369 3.2. Enzymatic Activity

\section{3.2.1. Browning-related Enzyme-Peroxidase (POD)}

371 The data for POD activity of fresh-cut tomato showed that samples treated with DWP 372 had significantly $(\mathrm{p}<0.05)$ lower activity compared to chlorine treated samples (Fig. 373 2C). Significant differences $(\mathrm{p}<0.05)$ in POD activity were observed among the DWP 374 treatments. Samples treated with DWP by a combination of dipping and spraying 375 method and DWP spraying showed significantly $(\mathrm{p}<0.05)$ lower POD activity than 376 samples treated with DWP dipping throughout the storage. The decreased activity of 377 POD in DWP treated samples might be associated with the potential antioxidant 378 activity of the whey permeate used (Peña-Ramos \& Xiong, 2003). A significant $379(\mathrm{p}<0.05)$ increase in the activity in all the samples was observed during storage 380 regardless of the treatments, although showing little fluctuations over storage. The 381 initial increase at day 3 might be due to mechanical stress during minimal processing 382 (Cantos et al., 2001). The depletion of antioxidants at day 10 might be attributed to 383 the sharp increase of POD activity in whey treated samples in the period of day 7 to 
384 10. Edible composite coatings prepared from whey protein concentrate and beeswax 385 with ascorbic acid or $0.5 \%$ cystine reduced the enzymatic browning of 'Golden 386 Delicious' apples (Perez-Gago et al., 2006).

\subsubsection{Texture-related Enzyme- Pectin Methyl Esterase (PME)}

Significant differences $(\mathrm{p}<0.05)$ were observed in PME activity among the samples treated with DWP and chlorine (Fig. 2D). Samples treated with chlorine showed significantly $(\mathrm{p}<0.05)$ lower PME activity than DWP treated samples. There was no significant difference $(\mathrm{p}>0.05)$ among the DWP treated samples. PME activity increased significantly $(\mathrm{p}<0.05)$ during storage for all treatments. Other authors have attributed that the variability of intrinsic factors and the pre- and postharvest factors can affect enzyme activity, vitamin content, etc of the samples (Yoo et al., 2009). Similar behaviour has been observed for certain browning related enzymes (PerezGago et al., 2006).

\subsection{Sensory Analysis}

Significant differences $(\mathrm{p}<0.05)$ for fresh appearance, aroma, texture and general acceptability scores were observed between samples treated with DWP and chlorine (Fig. 3). DWP treated fresh-cut tomatoes scored significantly higher $(\mathrm{p}<0.05)$ than chlorine treated samples. Among the samples treated with DWP, the combination of dipping and spraying scored the highest, followed by the spraying only. Lowest scores of fresh appearance, aroma, texture and general acceptability were observed in samples treated with DWP by dipping only among the three DWP treated samples. This was in agreement with most of the physico-chemical markers of fresh-cut tomatoes studied in the current research. All the attributes evaluated (such as, texture, aroma, first impression, general acceptability) decreased significantly $(\mathrm{p}<0.05)$ during 
408 storage which is associated with a loss of quality. However, the values at the end of 409 the storage (10 days) were still above the acceptability threshold of 5 for all the 410 attributes scored (Ferreira et al., 2008). The non-hypoxic $\mathrm{O}_{2}$ and $\mathrm{CO}_{2}$ concentration in

411 the packages might have helped to maintain acceptable levels of colour and aroma 412 (Aguayo et al., 2006). Nykänen et al. (1998) analysed the effect of nisin-whey 413 permeate washing solutions on total counts and sensory characteristics in rainbow 414 trout. They found that nisin-whey treatment caused no negative effect on sensory 415 attributes.

\section{$416 \quad 3.4 . \quad$ Nutritional Markers}

\subsubsection{Ascorbic Acid}

418 Ascorbic acid decreased significantly $(\mathrm{p}<0.05)$ during 10 days of storage for all 419 treatments (from $19 \mathrm{mg} / 100 \mathrm{~g} \mathrm{FW}$ to $15 \mathrm{mg} / 100 \mathrm{~g} \mathrm{FW}$ ). This result is in agreement 420 with Toor \& Savage (2005). Significant differences $(\mathrm{p}<0.05)$ were observed in 421 ascorbic acid content among the samples treated with DWP and chlorine (Fig. 4A). 422 Samples treated with chlorine retained the lowest ascorbic acid over storage. Samples 423 treated with DWP by a combination of dipping and spraying had significantly $424(\mathrm{p}<0.05)$ higher ascorbic acid content than the other two DWP treated samples after 42510 days of storage. However, there was no significant difference $(p>0.05)$ between the 426 samples treated with DWP by dipping and by spraying. Ascorbic acid contributes $28-$ $42738 \%$ to the antioxidant activity, while the remaining activity is mainly due to 428 phenolics in tomatoes (Toor \& Savage, 2005). Phenolic substances have been 429 reported to have a protective effect on the ascorbic acid.

430 3.4.2. Lycopene 
431 The average amount of lycopene in the tomato samples was $5.7 \mathrm{mg} / 100 \mathrm{~g} \mathrm{FW}$. The 432 treatments did not show a significant effect $(\mathrm{p}<0.05)$ on the lycopene concentration of 433 the samples during storage (Fig. 4B). Samples treated with chlorine retained the 434 lowest lycopene over storage. The highest lycopene content was observed in samples 435 treated with DWP by a combination of dipping and spraying, though the difference 436 was not significant $(\mathrm{p}>0.05)$. However, storage time had significant effect $(\mathrm{p}<0.05)$ on 437 the tomato samples. The lycopene content increased during storage. This is because 438 fruits biosynthesise carotenoids during ripening throughout storage time (Odriozola439 Serrano et al., 2008). On the other hand, Shi \& Le Maguer (2000) observed that 440 carotenoids are susceptible to oxidation in the presence of light, oxygen and low $\mathrm{pH}$. 441 Therefore, the increase in the lycopene concentration during 10 days of storage might 442 be due to the biosynthesis of lycopene induced by ripening and the low oxidation of 443 this carotenoid as a result of low availability of $\mathrm{O}_{2}$ in the package headspace.

\subsubsection{Total Phenols}

445 The total phenol content of tomato samples differed significantly over storage time

446 (Fig. 4C). Chlorine treated samples showed significantly $(\mathrm{p}<0.05)$ lower phenolic 447 content than DWP treated samples. All three DWP treated tomato samples maintained 448 similar level of phenolic content during storage. The total phenol content decreased 449 significantly $(\mathrm{p}<0.05)$ during storage irrespective of treatments. This was in 450 accordance with other studies (Toor \& Savage, 2005; Gil et al., 2002). The decrease 451 was slow until day 3. After this, all samples demonstrated a rapid decrease in the total 452 phenolic content. Chlorine treated samples decreased the most to a value of around $45319.8 \mathrm{mg}$ GAE/100 g FW from $21.0 \mathrm{mg}$ GAE/100 g FW over 10 days of storage. 454 Phenolics are the major antioxidant compounds in plant extracts. Toor \& Savage 
455 (2005) reported that phenolic compounds might contribute 60 to $70 \%$ antioxidant 456 activity of tomato extracts.

457 3.4.4. Antioxidant Activity Test - 2, 2-Diphenyl-1-picrylhydrazyl Radical 458 Scavenging Capacity Assay (DPPH)

459 The antioxidant capacity as measured by DPPH radical scavenging activity differed 460 significantly $(\mathrm{p}<0.05)$ between treatments $($ Fig. 4D). All three whey permeate treated 461 samples showed significantly $(\mathrm{p}<0.05)$ higher DPPH reduction than chlorine treated 462 samples. The higher antioxidant activity of whey permeates treated samples could be 463 associated with the intrinsic antioxidant activity of whey permeates (Ahmed et al., 464 2011a). Whey permeates might have also helped to retain the antioxidant activity of 465 tomato slices. These results could be related to the total phenolic content of the 466 samples since the samples containing higher phenolic content exhibited stronger 467 DPPH reduction and vice versa. There was no significant difference $(p>0.05)$ between 468 the samples treated with DWP by a combination of dipping and spraying and spraying 469 only. Samples treated with DWP by dipping only had the lowest DPPH reduction 470 among the three DWP treatments. On the other hand, the antioxidant capacity of 471 fresh-cut tomatoes depleted with storage time irrespective of the treatments. The 472 antioxidant activity was reduced on an average $\sim 4 \%$ over 10 days of storage at $4{ }^{\circ} \mathrm{C}$.

\section{3.5. Microbial Enumerations}

\subsubsection{Total Aerobic Counts}

475 Fresh-cut tomatoes stored at $4{ }^{\circ} \mathrm{C}$ had initial loads of total aerobic counts 476 approximately $\sim 4.5 \log \mathrm{cfu} / \mathrm{g}$. The DWP treated samples had significant difference $477(\mathrm{p}<0.05)$ of bacterial growth to those treated with chlorine (Fig. 5A). Samples treated with DWP by a combination of dipping and spraying showed the highest reduction ( 
$1.0 \log \mathrm{cfu} / \mathrm{g}$ ) of total counts than samples treated with chlorine after 10 days of storage. Samples treated with DWP by dipping only and spraying only also showed significantly $(\mathrm{p}<0.05)$ better reduction in total aerobic counts $(\sim 0.6 \log \mathrm{cfu} / \mathrm{g})$ than samples treated with chlorine after 10 days of storage. In fresh-cut tomatoes, total counts increased during storage for all the washing treatments. This increase was more obvious between days 7 and 10. The values of DWP treated samples at the end of the storage were lower than the recommended $10^{8} \mathrm{cfu} / \mathrm{g}$ for consumer consumption of fresh-cut vegetables (Alegria et al., 2010).

\subsubsection{Yeast and Moulds}

The initial loads of yeast and moulds of fresh-cut tomatoes stored at $4{ }^{\circ} \mathrm{C}$ was approximately $4 \log \mathrm{cfu} / \mathrm{g}$. This result was in agreement with the finding of Prakash et al. (2002) for diced tomato. Chlorine treated samples showed the highest yeast and moulds growth ( $7.0 \log \mathrm{cfu} / \mathrm{g}$, day 10$)$. DWP treated tomatoes showed significantly $(p<0.05)$ lower counts than chlorine treated samples (Fig. 5B). Samples treated with DWP by a combination of dipping and spraying showed the highest reduction $(\sim 1.2$ $\log \mathrm{cfu} / \mathrm{g}$ ) of yeast and moulds counts than samples treated with chlorine after 10 days of storage. DWP treated samples by spraying also showed significantly $(\mathrm{p}<0.05)$ better reduction in yeast and moulds counts $(\sim 0.8 \log \mathrm{cfu} / \mathrm{g})$ than samples treated with chlorine after 10 days of storage. Yeast and moulds increased significantly $(\mathrm{p}<0.05)$ for all the washing treatments with storage time.

The presence of antimicrobial peptides in the whey permeate might contribute to its antimicrobial capacity (Clare \& Swaisgood, 2003). Antimicrobial peptides have been identified from whey protein hydrolysates. The most studied are the lactoferrins, $\alpha_{\mathrm{S}^{-}}$ casein and $\alpha_{\mathrm{S} 2}$-casein (Mccann et al., 2006). These antimicrobial peptides act against different gram-positive and gram-negative bacteria (Escherichia, Helicobacter, 
504 Listeria, Salmonella and Staphylococcus), yeasts and filamentous fungi (Rizzello et 505 al., 2008; Fitzgerald \& Murray, 2006). The amphipathic nature of these peptides 506 presumably underlies their biological activities which enables them to associate with 507 lipid membranes and disrupt normal membrane functions of bacteria. The mechanism 508 of action has been investigated for whey antimicrobial peptides by Saint-Sauveur et 509 al. (2008).

\section{$510 \quad 4 . \quad$ Conclusion}

511 The results showed that the use of delactosed whey permeate (DWP) is a viable 512 alternative to chlorine in controlling the microbiota associated with the quality 513 deterioration of fresh-cut tomatoes, since the growth of total aerobic counts and yeasts 514 and moulds were substantially inhibited by its application. Moreover, DWP treated 515 samples retained the antioxidant compounds better during storage than the chlorine 516 treated samples. The three application methods of DWP differed significantly for 517 extending the shelf-life of fresh-cut tomatoes. The combination of dipping and 518 spraying of DWP showed the best results for all the markers tested. Further research 519 on antimicrobial and antioxidant properties of DWP is recommended.

\section{Acknowledgements}

521 The authors would like to acknowledge the financial support of the DIT Strand I 522 Research Project (2006-2010). Thanks to Glanbia (Ltd Ingredients, Ireland) for 523 supplying the whey permeate, to Amcor Flexible Ltd. for providing OPP film and to 524 Sharp Interpack for the polypropylene trays.

\section{References}


Aguayo E, Escalona VH \& Artes F (2006) Effect of cyclic exposure to ozone gas on physicochemical, sensorial and microbial quality of whole and sliced tomatoes. Postharvest Biology and Technology, 39, 169-177.

Ahmed L, Martin-Diana AB, Rico D \& Barry-Ryan C (2011a). The antioxidant properties of whey permeate treated fresh-cut tomatoes. Food Chemistry, 124, 1451-1457.

Ahmed L, Rico D, Martin-Diana AB \& Barry-Ryan, C (2011b). Optimization of application of delactosed whey permeate treatment to extend the shelf-life of fresh-cut tomato using response surface methodology. Journal of Agricultural and Food Chemistry, doi: 10.1021/Jf103809f.

Alegria C, Pinheiro J, Gonçalves EM, Fernandes I \& Moldão M (2010). Evaluation of a pre-cut heat treatment as an alternative to chlorine in minimally processed shredded carrot. Innovative Food Science and Emerging Technology, 11, $155-161$.

Artés F, Conesa MA, Hernández S \& Gil MI (1999). Keeping quality of fresh-cut tomato. Postharvest Biology and Technology, 17, 153-162.

Camargo GA., Grillo SLM, Mieli J \& Moretti RH (2010). Shelf life of pretreated dried tomato. Food and Bioprocess Technology, 3(6), 826-833.

Cantos E, Espin JC \& Tomas-Barberan FA (2001). Effect of wounding on phenolic enzymes in six minimally processed lettuce cultivars upon storage. Journal of Agricultural and Food Chemistry, 49(1), 322-330.

Chardonnet CO, Charron CS, Sams CE \& Conway WS (2003). Chemical changes in the cortical tissue and cell walls of calcium infiltrated 'golden delicious' apples during storage. Postharvest Biology and Technology, 28, 97-111. 
550 Clare DA \& Swaisgood HE (2000). Bioactive milk peptides (6). Journal of Dairy Science 83, 1187-1195.

552 Contreras MdelM, Hernández-Ledesma B, Amigo L, Martín-Álvarez PJ \& Recio I, (2011). Production of antioxidant hydrolyzates from a whey protein concentrate with thermolysin: optimization by response surface methodology. LWT - Food Science and Technology, 44, 9-15.

556 Coronado SA, Trout GR, Dunshea FR \& Shah NP (2002). Antioxidant effects of rosemary extract and whey powder on the oxidative stability of wiener sausages during 10 months frozen storage. Meat Science, 62, 217-224.

Delaquis PJ, Fukumoto LR, Toivonen PMA \& Cliff MA (2004). Implications of wash water chlorination and temperature for the microbiological and sensory properties of fresh-cut iceberg lettuce. Postharvest Biology and Technology,

Evans J, Zulewska J, Newbold M, Drake MA \& Barbano DM (2010). Comparison of composition and sensory properties of $80 \%$ whey protein and milk serum

Ferreira VO, Pinho O, Amaral M \& Martins I (2008). Application of blended-learning protein concentrates. Journal of Dairy Science, 93, 1824-1843. strategies on sensory analysis teaching. in M. Munoz, I. Jelinek, \& F. Ferreira (Eds.). Proceedings of The Iask International Conference Teaching and Learning, pp. 262-270. Aveiro, Portugal.

570 Fitzgerald RJ \& Murray BA (2006). Bioactive peptides and lactic fermentations. International Journal of Dairy Technology, 59, 118-125.

572 Gil MI, Conesa MA \& Artes F (2002). Quality changes in fresh cut tomato as affected by modified atmosphere packaging. Postharvest Biology and Technology, 25, 199-207. 
Lana MM, Tijskens LMM \& Van Kooten O (2006). Effects of storage temperature and stage of ripening on rgb colour aspects of fresh-cut tomato pericarp using video image analysis. Journal of Food Engineering, 77, 871-879.

Lee HS \& Castle WS (2001). Seasonal changes of carotenoid pigments and colour in hamlin, eartygold, and budd blood orange juices. Journal of Agricultural and Food Chemistry, 49, 877-882.

Lenucci MS, Cadinu D, Taurino M, Piro G \& Dalessandro G (2006). Antioxidant composition in cherry and high-pigment tomato cultivars. Journal of Agricultural and Food Chemistry, 54, 2606-2613.

Martin-Diana AB, Rico D, Frias JM, Mulcahy J, Henehan GTM \& Barry-Ryan C (2006). Whey permeate as a bio-preservative for shelf life maintenance of fresh-cut vegetables. Innovative Food Science and Emerging Technology, 7, 112-123.

Mccann KB, Shiell BJ, Michalski WP, Lee A, Wan J, Roginski H \& Coventry MJ (2006). Isolation and characterization of a novel antibacterial peptide from bovine $\alpha_{\mathrm{s} 1}$-casein. International Dairy Journal, 16, 316-323.

Nykänen A, Lapvetelainen A, Hietnen RM \& Kallio H (1998). The effect of acetic acid, nisin-whey permeates sodium chloride and related combinations on aerobic plate count and the sensory characteristics of rainbow trout. LWT Food Science and Technology 3, 286-290.

Odriozola-Serrano I, Soliva-Fortuny R \& Martin-Belloso O (2008). Effect of minimal processing on bioactive compounds and color attributes of fresh-cut tomatoes. LWT - Food Science and Technology, 41, 217-226.

Panesar PS, Kennedy JF, Gandhi DN \& Bunko K (2007). Bioutilisation of whey for lactic acid production. Food Chemistry, 105, 1-14. 
600 Pena-Ramos EA \& Xiong YL (2003). Whey and soy protein hydrolysates inhibit lipid

601

602

603

604

605

606

607

608

609

610

611

612

613

614

615

616

617

618

619

620

621

623

oxidation in cooked pork patties. Meat Science, 64, 259-263.

Perez-Gago MB, Serra M \& Del Rio MA (2006). Colour change of fresh-cut apples coated with whey protein concentrate-based edible coatings. Postharvest Biology and Technology, 39, 84-92.

Prakash A, Guner A, Caporaso F \& Foley D (2000). Effects of low-dose gamma irradiation on the shelf-life and quality characteristics of cut romaine lettuce packaged under modified atmosphere. Journal of Food Science, 65(3), 549553.

Rico D, Martin-Diana AB, Barat JM \& Barry-Ryan C (2007). Extending and measuring the quality of fresh-cut fruit and vegetables: a review. Trends in Food Science and Technology, 18, 373-386.

Rizzello CG, Losito I, Gobbetti M, Carbonara T, Bari MdeD \& Zambonin PG (2005). Antibacterial activities of peptides from the water-soluble extracts of italian cheese varieties. Journal of Dairy Science, 88, 2348-2360.

Rojas-Graü MA, Soliva-Fortuny R \& Martín-Belloso O (2009). Edible coatings to incorporate active ingredients to fresh-cut fruits: a review. Trends in Food Science and Technology, 20(10), 438-447.

Román A, Wang J, Csanádi J, Hodúr C \& Vatai G (2011). Experimental Investigation of the Sweet Whey Concentration by Nanofiltration. Food and Bioprocess Technology, 4(5), 702-709.

Saint-Sauveur D, Gauthier SF, Boutin Y \& Montoni A (2008). Immunomodulating properties of a whey protein isolate, its enzymatic digest and peptide fractions. International Dairy Journal, 18, 260-270. 
624 Sanchez-Moreno C (2002). Methods used to evaluate the free radical scavenging activity in foods and biological systems. Food Science and Technology International, 8, 121-137.

627

Sgherri C, Kadlecova Z, Pardossi A, Navari-Izzo F \& Izzo, R (2008). irrigation with diluted sea water improves the nutritional value of cherry tomatoes. Journal of Agricultural and Food Chemistry, 56, 3391-3397.

Shi J \& Le Maguer M (2000). Lycopene in tomatoes: chemical and physical properties affected by food processing. Critical Reviews in Food Science and Nutrition, 40(1), 1 - 42.

Singleton VL, Orthofer R \& Lamuela-Raventos RR (1999). Analysis of total phenols and other oxidation substrates and oxidants by means of folin-ciocalteu reagent. Methods Enzymology, 299, 152-178.

Toor RK \& Savage GP (2005). Antioxidant Activities in Different Fractions of Tomato. Food Research International, 38, 487-494.

Villanueva MJ, Tenorio MD, Sagardoy M, Redondo A \& Saco MD (2005). Physical, chemical, histological and microbiological changes in fresh green asparagus (Asparagus officinalis, L.) stored in modified atmosphere packaging. Food Chemistry, 91, 609-619.

Yalcin AS (2006). Emerging therapeutic potential of whey proteins and peptides. Current Pharmaceutical Design, 12(13), 1637-1643.

Yoo YH, Lee S, Kim Y, Kim KO, Kim YS \& Yoo S.H (2009). Functional characterization of the gels prepared with pectin methylesterase (PME)treated pectins. International Journal of Biological Macromolecules, 45, 226230. 
650 Fig. 1. Effect of treatments on headspace gas composition $\mathrm{O}_{2}(\mathrm{~A})$ and $\mathrm{CO}_{2}(\mathrm{~B})$ in

651 fresh-cut tomato packages over 10 days storage at $4{ }^{\circ} \mathrm{C}$. Points designated on any 652 curve by different letters are significantly different $(\mathrm{p}<0.05)$. Lower case letters are 653 used for comparisons during storage and upper case letters for treatment comparisons.

654 Three independent trials were carried out in triplicate.

655 Fig. 2. Effect of DWP and chlorine treatments on pH (A), texture (B), POD (C) and 656 PME (D) in fresh-cut tomato packages over 10 days storage at $4{ }^{\circ} \mathrm{C}$. Points designated 657 on any curve by different letters are significantly different $(\mathrm{p}<0.05)$. Lower case 658 letters are used for comparisons during storage and upper case letters for treatment 659 comparisons. Three independent trials were carried out in triplicate.

660 Fig. 3. Sensory evaluation of fresh-cut tomatoes packaged and stored for 10 days at 4 $661{ }^{\circ} \mathrm{C}$ and treated with DWP and chlorine.

662 Fig. 4. Ascorbic acid (A), lycopene (B), total phenols (C) and antioxidant activity 663 DPPH (D) in fresh-cut tomatoes treated with DWP and chlorine during the 10 days of 664 storage at $4{ }^{\circ} \mathrm{C}$. Points designated on any curve by different letters are significantly 665 different $(\mathrm{p}<0.05)$. Lowercase letters are used for comparisons during storage and 666 uppercase letters for treatment comparisons. Three independent trials were carried out 667 in triplicate.

668 Fig. 5. Effect of washing treatments on total aerobic counts (A) and yeast and moulds 669 (B) during 10 days storage of fresh-cut tomato at $4{ }^{\circ} \mathrm{C}$. Points designated on any curve 670 by different letters are significantly different $(\mathrm{p}<0.05)$. Lowercase letters are used for 671 comparisons during storage and uppercase letters for treatment comparisons. Three 672 independent trials were carried out in triplicate. 
Fig. 1

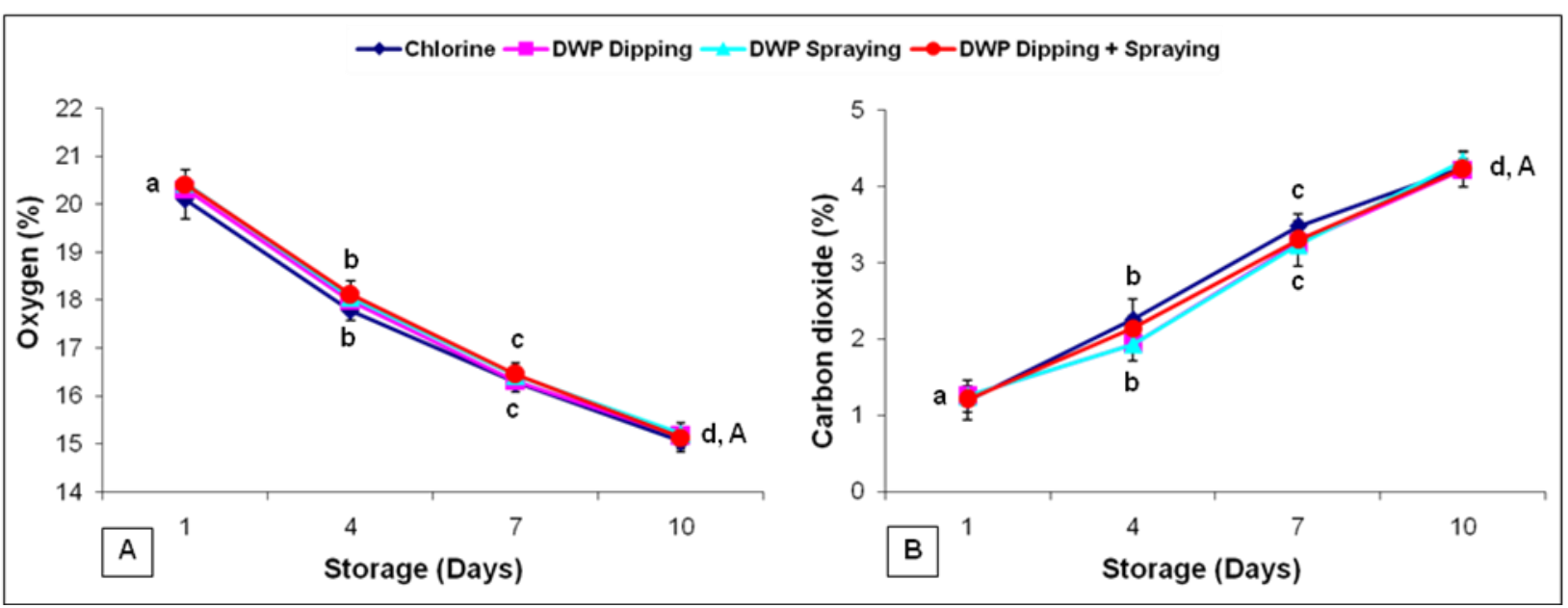

Fig. 2

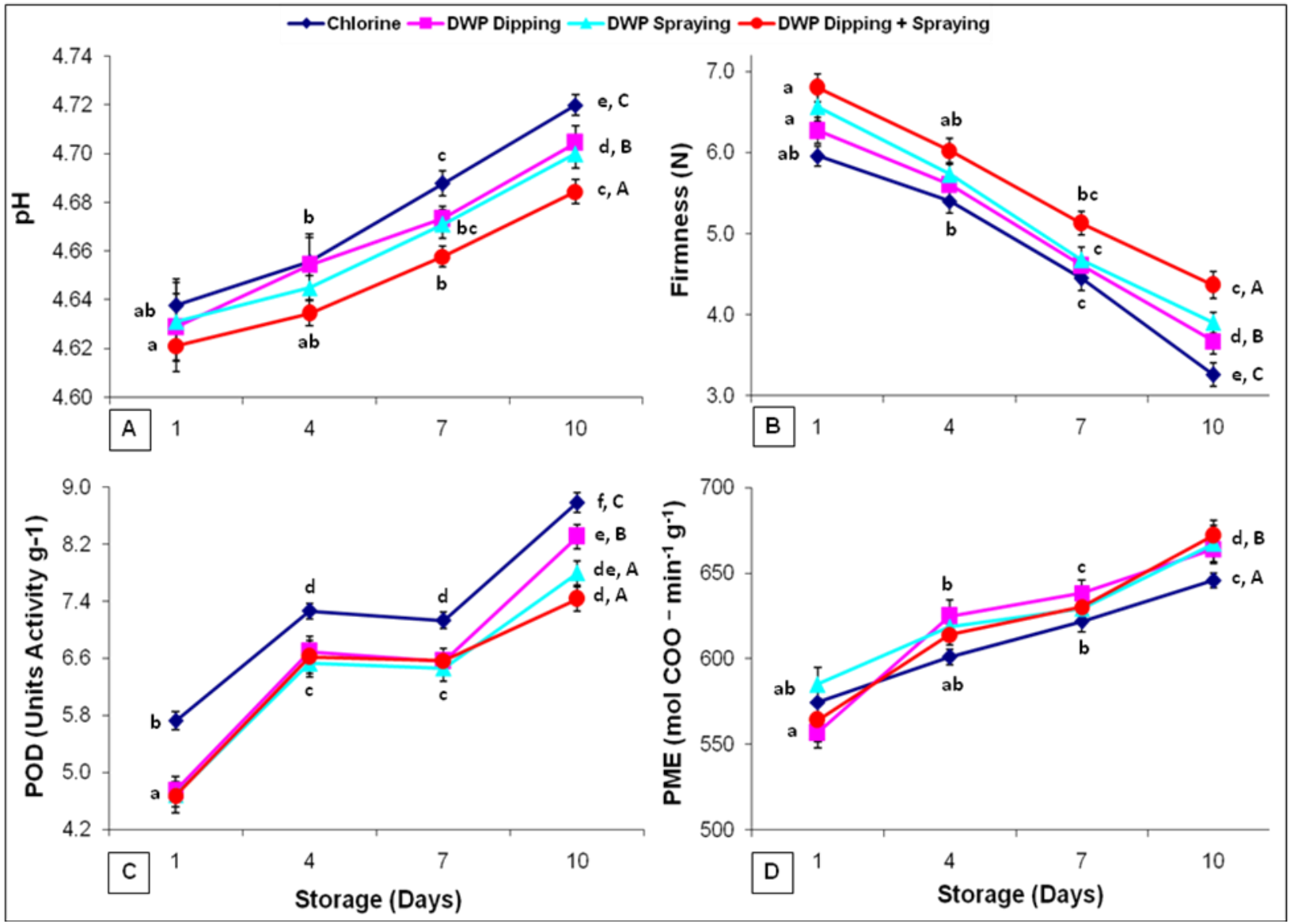


Fig. 3

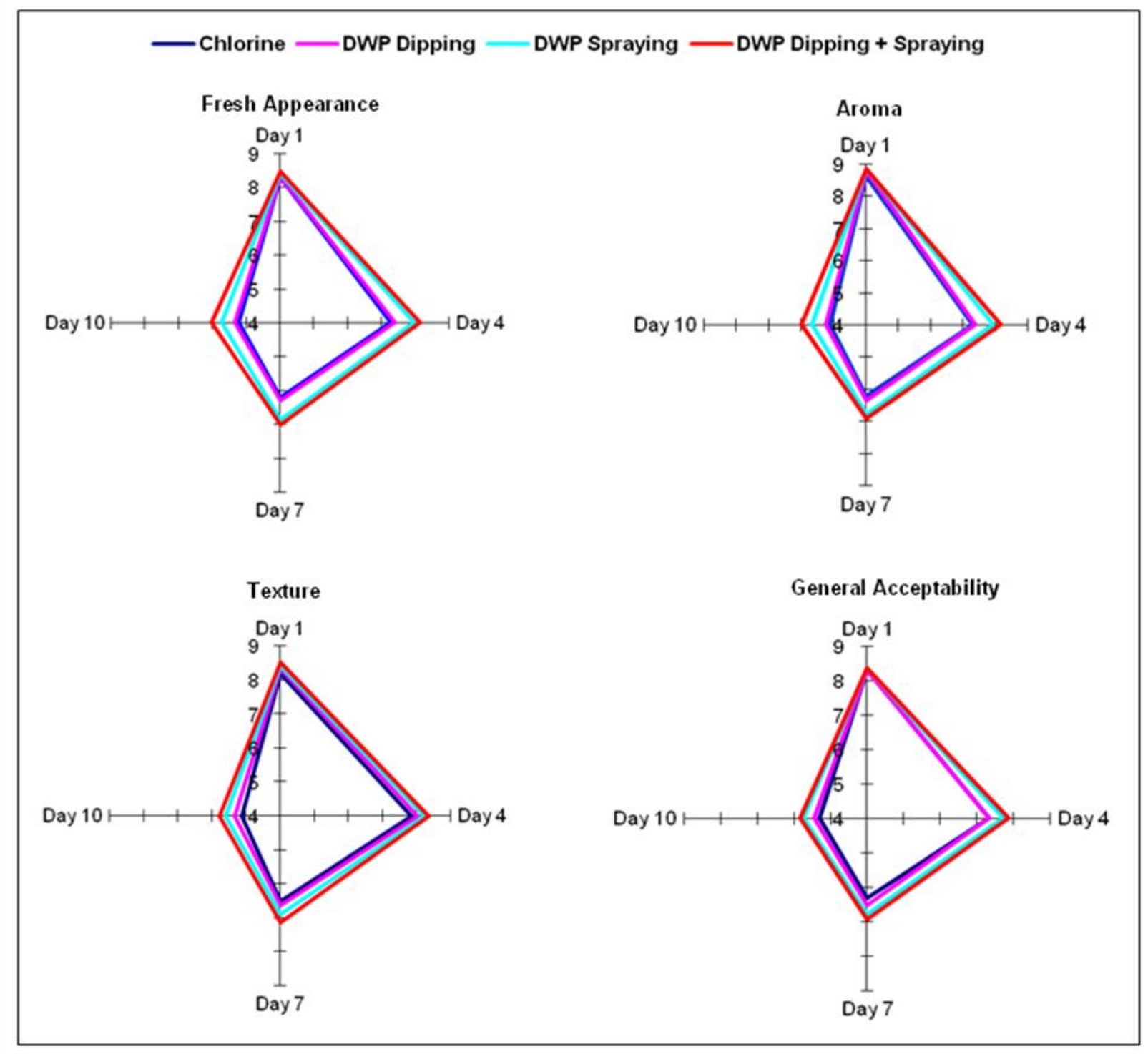

676 
Fig. 4

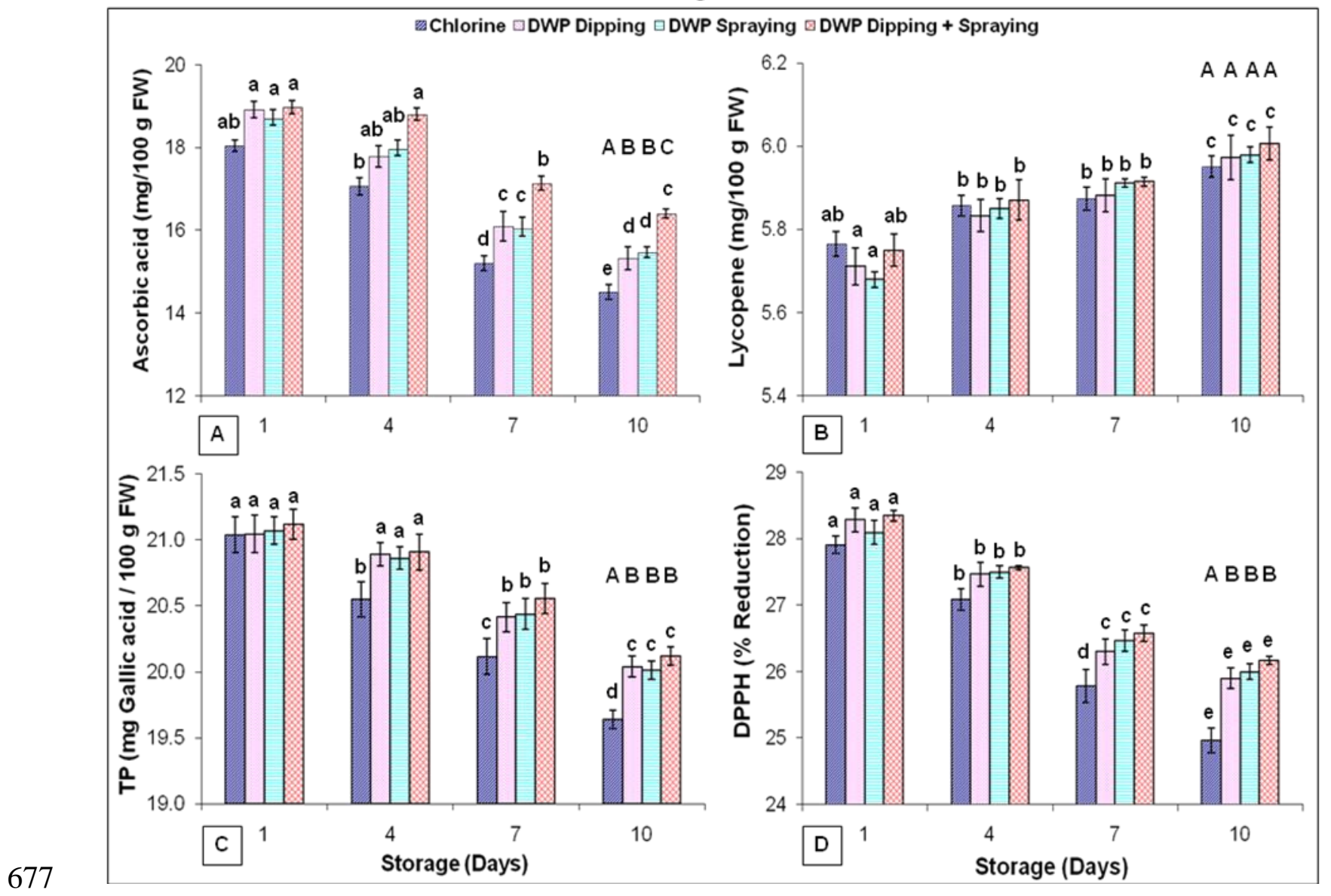

Fig. 5

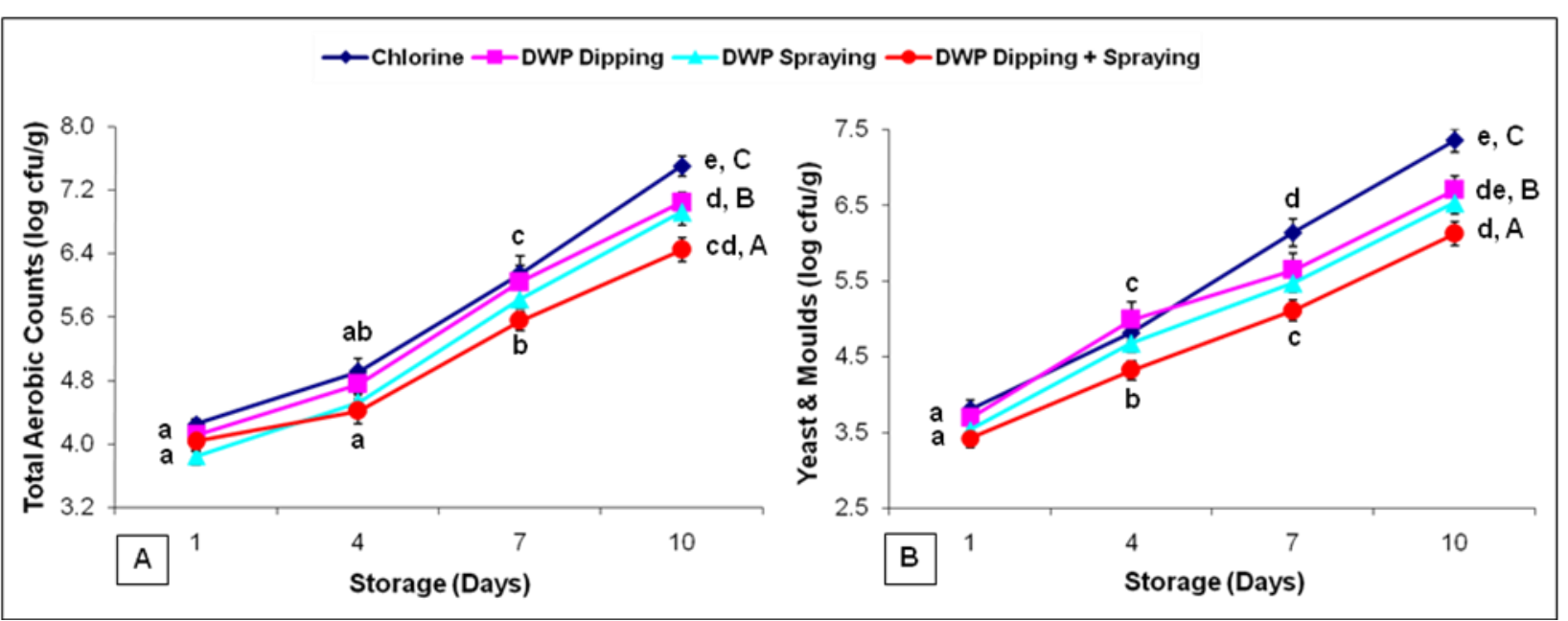

